\title{
NOTKI RECENZYJNE
}

Pamiętniki i relacje w zbiorach rękopiśmiennych BN (wydanie drugie poprawione $i$ rozszerzone), oprac. Danuta Kamolowa; przy współudziale Teresy Sieniateckiej, Warszawa: Biblioteka Narodowa, 2015, 539, [1] s., [26] k. tabl.: il., ISBN 978-83-7009-623-6.

Pamiętnikarstwo stanowi ciekawe źródło dla badaczy różnych dziedzin, głównie ze względu na podejmowany w nim opis poznawanego świata. Może kryć zasoby cennych informacji umożliwiających poznanie osób i zdarzeń, subiektywnych stron życia społecznego, narracji historycznej, obyczajów. Może też ułatwić prowadzenie badań nad daną epoką ${ }^{1}$. W Rzeczypospolitej pamiętnikarstwo dość intensywnie zaczęło rozwijać się od schyłku XVIII w. i z czasem stało się modne. W ciągu kilku stuleci powstało wiele pamiętników, relacji i innych materiałów o charakterze osobistym. Część tego dziedzictwa memuarystycznego zachowało się do dzisiaj i wchodzi w skład rękopiśmiennego zbioru Biblioteki Narodowej. Zbiór manuskryptów, choć znacznie uszczuplony w czasie II wojny światowej, cieszy się obecnie dużym zainteresowaniem badaczy, dlatego też w 2015 r. opublikowane zostało drugie, rozszerzone wydanie $P a$ miętników i relacji w zbiorach rękopiśmiennych $B N$, opracowane przez Danutę Kamolową przy współudziale Teresy Sieniateckiej.

Pierwsza edycja ukazała się w 1998 r., gdy zasób pamiętników i relacji liczył około 1000 tego typu dokumentów. Wydanie drugie zostało uzupełnione o nabytki z lat 1997-2012, dzięki którym kolekcja poszerzyła się o ponad 1300 pozycji, w tym o pamiętniki staropolskie, relacje z podróży, opisy bitew i wypraw wojennych. Warto jednak podkreślić, że większość zgromadzonych w Bibliotece Narodowej i omówionych w publikacji manuskryptów o tym charakterze to dzienniki i wspomnienia pisane w XIX i XX w. ${ }^{2}$

Jak podkreślają autorki, celem pracy było przede wszystkim wprowadzenie czytelnika w treść pamiętników, barwnie opisujących wydarzenia i losy autorów, ich rodzin i środowisk. Nie jest ona sensu stricto ani katalogiem, ani tym bardziej przewodnikiem ${ }^{3}$.

Główna część publikacji zawiera opisy pamiętników polskich i, w przeciwieństwie do wydania pierwszego, obcych. Polski materiał został ułożony w po-

1 Zob. E. Kula, Karol Witte (1814-1878). Sylwetka opracowana na podstawie materiatów archiwum rodzinnego Korzeniowskich w zbiorach Biblioteki PAU i PAN w Krakowie, „Studia Pedagogiczne Akademii Świętokrzyskiej” 2005, t. 15, s. 245.

2 Z XVI w. - siedem pamiętników, z XVII w. - 20, a z XVIII w. - 34.

3 Zob. Pamiętniki i relacje $w$ zbiorach rękopiśmiennych BN, oprac. D. Kamolowa; przy współudziale T. Sieniateckiej, Warszawa 2015, s. 13. 
rządku alfabetycznym według autorów memuarów. Badaczki zdają sobie sprawę z możliwych niedogodności związanych z takim rozwiązaniem. Jak zauważają:

w wielu wypadkach bardziej stosowny byłby porządek chronologiczny czy tematyczny. Przeważyły jednak argumenty świadczące o tym, że układ alfabetyczny będzie najwygodniejszy i najbardziej klarowny4.

W strukturę opisu każdej pozycji wchodzą trzy składowe: 1. nazwisko i imię autora oraz informacje biograficzne: lata życia, wykonywany zawód czy pozycja w środowisku; 2. tytuł w formie nadanej przez autora, a w przypadku jego braku - nadany przez autorki publikacji; 3. opis zawartości teczki w formie abstraktu, w miarę możliwości według tematów: środowisko, rodzina, szkoły, udział w organizacjach, powstania i wojny, działalność zawodowa, podróże itp. ${ }^{5}$

Korzystanie z publikacji ułatwia aż pięć indeksów: 1. osobowy, 2. instytucji, organizacji i tytułów czasopism, 3. geograficzny, 4. rzeczowy, 5. proweniencji. Dodatkowo zamieszczony został wykaz konkordancji sygnatur i numerów pozycji, która zawiera spis sygnatur stałych i akcesji. Podano tam także sygnatury ze zbiorów Biblioteki Ordynacji Zamojskiej.

Na pochwałę zasługuje szata edytorska wydawnictwa - bardzo przejrzysta i staranna. Niekiedy pojawiają się też ilustracje świadczące o różnorodności materiałów, jakie zostały przedstawione w tym opracowaniu.

Zgromadzony materiał to bogate źródło badawcze dla różnych obszarów nauk humanistycznych. Opisanie tak różnorodnych materiałów w formie przyjaznego dla czytelnika informatora z pewnością przyczyni się do jeszcze większego wykorzystania tego typu źródeł przez badaczy.

Katarzyna Seroka Warszawa

Anna Kocot, Artyści „czarnej sztuki”. Typografia druków Floriana Unglera i Macieja Wirzbięty, Kraków: Księgarnia Akademicka, 2015, ss. 416, ISBN/ISSN 978-83-76384-60-3.

W ramach wydawanej od 1994 r. przez Bibliotekę Jagiellońską serii „Bibliotheca Jagiellonica. Fontes et studia”, ukazała się (jako tom 26) książka omawiająca typografię druków opublikowanych przez dwie XVI-wieczne krakowskie oficyny wydawnicze: Floriana Unglera i Macieja Wirzbięty. Owa seria ma na celu pokazanie bogatych zasobów jakie kryją do dzisiaj

4 Zob. tamże, s. 14.

Zob. tamże, s. 15. 
magazyny Biblioteki Jagiellońskiej, zaś autorami poszczególnych tomów są pracownicy książnicy uniwersyteckiej lub innych krakowskich instytucji nauki i kultury. Anna Kocot jest jednym z tych autorów.

Ta duża, licząca przeszło 400 stron praca, składa się z trzech części. Pierwsza i druga dotyczy oficyny wydawniczej F. Unglera z lat 1510-1516 (I drukarnia) oraz 1521-1536 (II drukarnia), a ostatnia typografii M. Wirzbięty (1555/1557-1605). Obszerny, ale nie za długi Wstęp oraz cenne wnioski w Zakończeniu, wykaz literatury przedmiotu, indeksy, podsumowanie w języku angielskim oraz fotografie kart tytułowych utworów, które wyszły spod pras analizowanych wydawnictw, składają się na interesującą całość tej potrzebnej, nie tylko dla bibliologów, książki.

Zadaniem pracy było ukazanie ewolucji typograficznej druków krakowskich w XVI w. W tym celu Autorka porównała publikacje ukazujące się w oficynie Unglera w pierwszej połowie XVI w. z tymi, które ujrzały światło dzienne w drukarni M. Wirzbięty. Konfrontacja druków pozwoliła na wskazanie podobieństw i różnic $\mathrm{w}$ ich budowie i opracowaniu edytorsko-typograficznym (s. 24). Na użytek tej pracy A. Kocot przyjęła typologię druków i terminologię, którą posługiwali się autorzy wydawnictwa Polonia Typographica Saeculi Sedecim. Ale w wielu wypadkach musiała zastosować własne nazewnictwo, ponieważ nie używano go w cytowanym wydawnictwie (np. układ elementów ozdobnych, szlaczki z przerywników, linie komponowane z elementów typograficznych i wiele innych, s. 26). Warto podkreślić, że stosowana terminologia została dokładnie przez Autorkę wyjaśniona. Gruntowna kwerenda przeprowadzona w najważniejszych bibliotekach polskich (BJ, BCzart., Bibliotece Naukowej Księży Jezuitów w Krakowie, Bibliotece Muzeum Narodowego w Krakowie, BN, BUW i w zasobach Federacji Polskich Bibliotek Cyfrowych), pozwoliła przeanalizować prawie 98\% druków obu typografów, zidentyfikowanych i do dziś zachowanych (s. 27). A. Kocot opisywała, a następnie porównywała w książkach pochodzących z obu wydawnictw te same cechy fizyczne, układ tekstu w obrębie akapitu, układ strony, materiał zdobniczo-ilustracyjny, ramy wydawnicze (s. 28). Pominęła superekslibrisy i oprawy jako elementy książki powstałe poza drukarnią. Na potrzeby swojej rozprawy Autorka stworzyła bazę danych, w której zamieściła wszystkie elementy składające się na kompozycję typograficzno-edytorską druków Unglera i Wirzbięty. Dzięki niej opisała kanon estetyczny publikacji wspomnianych tłoczni oraz jego oddziaływanie na inne krakowskie oficyny drukarskie. Wprawdzie porównywać estetykę książek wychodzących z wymienionych wyżej zakładów jest dosyć trudno, ale można wskazać obowiązujące wówczas mody czy tendencje w edycji druków.

Część pierwsza książki poświęcona jest analizie druków z pierwszej oficyny F. Unglera, działającej w latach 1510-1516. Zdaniem Autorki całe przed- 
sięwzięcie drukarskie traktował impresor jako pewnego rodzaju eksperyment. Bez dużych pieniędzy, doświadczenia zawodowego trudno było Unglerowi utrzymać się na krakowskim rynku wydawniczym. Oczekiwanych sukcesów nie przyniósł ani druk książki w języku polskim - Raj duszny (Hortulus animae, 1513) w thumaczeniu Biernata $\mathrm{z}$ Lublina, ani poszukiwane na rynku książki religijne, prace astrologiczne, iudicia, prognostyki, podręczniki szkolne, prace profesorów Akademii Krakowskiej, czy pieśni dedykowane królowi Zygmuntowi Staremu. Znacznie lepiej prosperowała dopiero druga oficyna, działająca w latach 1521-1536. W unglerowej drukarni ukazywały się prace ówczesnych polskich humanistów, chętnie czytanych również poza Polską (np. Andrzeja Krzyckiego, Jana Libanusa, Jana Tucholczyka, Mikołaja z Szadka, Grzegorza z Szamotuł). Henryk Bułhak podkreślał, że dzięki uporowi i chęci do podejmowania ryzyka, F. Ungler stworzył placówkę o wielkim znaczeniu dla kultury polskiej (s. 38-40). Dysponował 13. rodzajami pisma z czego dziesięć było jego własnych, a trzy pożyczył od Jana Hallera. Brak czcionek polskich utrudniał druk po polsku. Ungler starał się podnieść wartości estetyczne swoich druków między innymi modernizując materiał ilustracyjny. Drzeworyty pełniły w jego książkach zarówno funkcje dekoracyjne, jak i ilustrowały tekst. Czytelnikami książek Unglera byli studenci i mieszczanie (s. 110). Bardziej luksusowe wydania trafiały do ówczesnej elity duchownej i świeckiej. Odbiorcami tych wydań był przede wszystkim dwór królewski oraz dostojnicy kościoła katolickiego. W ponownych edycjach wykorzystywano „nową estetykę". W okresie pierwszej oficyny wznowienia miało tylko pięć dzieł i były to książki naukowe, zapewne potrzebne studentom. A. Kocot podkreśla, że w reedycjach zachowywano poprzedni format druku, czcionkę. Eksperymentowano tylko z materiałem zdobniczym (s. 116). Zdaniem Autorki na szczególną uwagę zasługują edycje: Epithalamion ... Sigismundi regis... Pawła z Krosna (1512), Jana Burcharda Ordo missae cum glossa Stanislai Zaborowski (1512), Walentego Ecka Panegyricvs in Lavde $[\mathrm{m}]$... Augustini Moraui... (1513), Epithoma utrisq[ue] musices... Stefana Monetariusa (1515) i Carmina ... de felicissimo reditu ex Vienna austriaca ... Sigismundi regis Poloniae... Pawła z Krosna (1515).

Druga część pracy poświęcona jest kolejnym losom oficyny Unglera przypadającym na lata 1521-1536. W typografii korzystał z nowych czcionek, gdyż część poprzednich została zniszczona podczas pożaru oficyny. W dalszym ciągu udoskonalał kroje pism oraz drzeworyty, zarówno ilustracyjne, jak i dekoracyjne. W tym okresie swej działalności oficyna korzystała w większym niż poprzednio stopniu z papieru miejscowego (krakowskiego), a wydawane wtedy książki miały bardziej zróżnicowane formaty, związane z typem i treścią. Dzięki przywilejom królewskim Ungler otrzymał monopol na druk rubryceli w formacie in octavo (s. 148). Wydawał bardzo różnorodne 
książki, które przynosiły zyski właścicielowi i sławę autorom. W drugiej oficynie Unglera ukazywały się kalendarze, książki prawnicze, kazania, mowy, poezje, pisma polemiczne o tematyce religijnej, prace autorów renesansowych i antycznych, podręczniki oraz poradniki, pisane po łacinie i polsku (s. 149). Wyjątkowym przedsięwzięciem typograficznym były mapy Bernarda Wapowskiego.

Podobnie jak w poprzednim warsztacie dominował druk dwubarwny, a dodatkowy kolor stosowano tylko w edycjach luksusowych, w których wykorzystywano duże ornamenty drzeworytowe wypełniające wolne miejsca na stronie (s. 150). Sygnety z karty tytułowej trafily na ostatnia kartę (s. 219). W miejsce drzeworytu i laudacji na cześć wydawcy zamieszczano coraz częściej informacje o autorze. Tylko siedem druków miało powtórne edycje, a wprowadzane zmiany estetyczne były niewielkie (s. 199). W drugiej oficynie Unglera ukazały się prace szczególnie interesujące edytorsko. Należały do nich Ivdicivm Paridis... (1522) Jakuba Lochera, Żywot Pana Jesusa Krysta w thumaczeniu Baltazara Opecia, Oratio cora $[\mathrm{m}]$... Sigismvndo Poloniae Rege... (1523) Bernarda Wapowskiego, ozdobne wydania Biblii, O ziolach y o moczy gich ... Stefana Falimirza (1534), Dyalogus ... iuvenibus scholaribus perutilissimus (1523) Donatusa.

Zdaniem A. Kocot druki Unglera ,nie zasługiwały na miano pięknych ale widać w nich potrzebę doskonalenia jakości” (s. 219). Prace tych samych autorów wydawane przez innych drukarzy krakowskich były od strony typograficznej podobne, ale unglerowskie były bardziej ubogie estetycznie, niż te publikowane przez konkurencję, np. Wietora.

Ostatnia, trzecia część pracy pokazuje działalność drukarską M. Wirzbięty. Przez wielu badaczy był on uznawany za drukarza różnowierców, a szczególnie Mikołaja Reja. Właśnie poeta miał być wspólnikiem drukarza i wpływać na repertuar wydawniczy oficyny (s. 230). Wielu znawców problematyki (Alodia Kawecka-Gryczowa, Elżbieta Stankiewicz) uważa, że książki wychodzące z typografii Wirzbięty są piękne pod względem estetyki (s. 231). M. Wirzbięta był dobrze wykształcony, sam próbował pisać i tłumaczyć innych autorów i to też miało wpływ na jego wybory estetyczne.

Większość książek Wirzbięty, podobnie jak w drugiej oficynie Unglera, powstała na bardzo dobrym papierze krakowskim. Podstawowym formatem druku było jednobarwne in quarto (s. 253). Kolor czerwony występował sporadycznie, zaś czcionka, jej krój związany był z językiem druku. Teksty polskie składano czcionkami gotyckimi, druki łacińskie antykwą i kursywą. Do tekstów greckich i hebrajskich stosowano inne pisma. Dominował blokowy skład strony. Elementem ozdobnym były serie inicjałowe bez ramek. Winietki stosowano tylko w edycjach luksusowych. Druki były bardziej czytelne niż unglerowskie. Standardem była żywa pagina, marginalia 
i kustosze. Teksty zdobiły piękne inicjały. Informacje z kolofonu trafiały na stronę tytułową. Ostatnia karta druku była pusta lub zaopatrzona w sygnet drukarski (s. 347). Druki M. Wirzbięty coraz bardziej przypominały dzisiejszą książkę. W podsumowaniu Autorka napisała, że „Typografowi udało się połączyć dobry gust z solidnym wykształceniem zawodowym wzbogaconym zapewne nowinkami z renomowanych drukarń zagranicznych" (s. 349). Postylla M. Reja stała się wzorcem edytorskim również dla katolickich impresorów, wzorowano na niej edycje kazań Jakuba Wujka i teksty Piotra Skargi. Zdaniem A. Kocot „Wirzbięta pozostawił w tyle druki Unglera ale daleko mu było jeszcze do wydań prac wychodzących z pras Januszowskiego" (s. 355).

W Zakończeniu Autorka wyraźnie podkreśliła, że książki Unglera i Wirzbięty bardzo się między sobą różniły, ale miały też wiele cech wspólnych. Łączyły je formaty. Książki obu wydawców były poręczne, podróżowały wraz z właścicielami, dlatego wśród nich dominowały formaty in quarto oraz in octavo. Autorka pokazuje związek formatu z typem dzieła. Książki drukowano antykwą i kursywą. Omawiane oficyny, oprócz czcionek łacińskich, posiadały też czcionki z alfabetem greckim i hebrajskim. Teksty w języku narodowym tłoczono gotykiem. I w tym m.in. przejawia się wpływ drukarstwa niemieckiego na polskie. Za pomocą różnorodnych środków typograficznych pokazywano zróżnicowanie treści. W drukach tekst komponowano na stronie blokowo, natomiast dwukolumnowość była zjawiskiem marginalnym i pojawiała się w książkach wielkoformatowych i tradycyjnych. We wczesnych drukach unglerowskich dominowały pozostałości rękopiśmiennego, średniowiecznego układu tekstu, ale w późniejszych wykształcił się nowy model budowy strony. Rewers karty tytułowej pozostawał pusty, a kolofon i karta tytułowa były jednocześnie w tych samych publikacjach, chociaż znikł adres wydawniczy na końcu książek. Zdaniem Autorki największe zmiany dotyczyły karty tytułowej. „Ciężkie” zdobienia drzeworytowe zastąpiły delikatne winietki. Zamiast epigramatów umieszczano na nich motta lub umoralniające sentencje (s. 362). W drukach Wirzbięty tytuły składano w sposób bardzo czytelny a mniej ozdobny. W drukach unglerowskich rewers karty tytułowej miał zaś bogatą ornamentykę. Uproszczeniu uległy też ramy wydawnicze i materiał zdobniczy. W drugiej oficynie Unglera i u Wirzbięty drzeworyty stały się ważnym uzupełnieniem tekstu; ich rola była niezwykle znacząca zwłaszcza w pracach naukowych i religijnych. Zielnik Falimirza z oficyny Unglera jest najlepszym przykładem połączenia tekstu z ilustracjami. Taka tendencja dominowała w ówczesnym drukarstwie europejskim.

Standardy estetyczne książek w XVI w. pokazywały edycje luksusowe. Za piękne uważano druki, których ,główną ozdobą była drzeworytowa 
bordiura otaczająca całość tekstu lub tylko elementy ramy wydawniczej” (s. 364). W edycjach luksusowych mógł się pojawiać druk dwubarwny.

Analiza wybranych druków pokazała, że w XVI w. udało się impresorom uporządkować układ akapitu i strony oraz wewnętrzny podział tekstu. Nauczono się łączyć ilustracje z tekstem. Wprowadzono także indeksy, erraty, numeracje i odsyłacze. Strony tytułowe stały się czytelne. W publikacji A. Kocot bardzo interesująco przedstawia się zebranie w postaci tabel szczegółowych różnic w zasobie typograficznym przebadanych druków (s. 365-372).

W podsumowaniu Autorka dokonała porównań drukarstwa francuskiego i polskiego. Podkreślała, że istniały wielkie podobieństwa między XVI-wieczną krakowską a europejską książką drukowaną. Krakowscy wydawcy ciągle podnosili jej estetykę czerpiąc z najlepszych europejskich wzorów. Dobrze dobrane ilustracje, imponujący wykaz źródeł i literatury przedmiotu oraz indeks stanowią dopełnienie tej interesującej książki.

Anna Kamler

Warszawa

Justyna Kiliańczyk-Zięba, Sygnety drukarskie w Rzeczypospolitej XVI wieku: źródta ikonograficzne i treści ideowe, Kraków: Wydawnictwo Towarzystwa Naukowego „Societas Vistulana” 2015, 342, [1] s. : il., ISBN 978-83-61033-89-9.

Sygnety drukarskie, czyli niewielkie kompozycje graficzne, służyły w przeszłości drukarzom jako znaki handlowe, dzięki którym można było zidentyfikować ich wytwory. Użyte przez nich symbole nie należały do przypadkowych - odnosiły się np. do tożsamości, korzeni czy nazwiska typografa, ale niekiedy były „rebusowym podpisem”.

Używanie skomplikowanych kompozycji graficznych często miało stanowić intelektualne wyzwanie dla czytelnika, pełniło funkcję umysłowej rozrywki, a niekiedy nawet chroniono w ten sposób dzieło przed cenzurą ${ }^{2}$. Justyna Kiliańczyk-Zięba poświęciła publikację Sygnety drukarskie w Rzeczypospolitej XVI wieku właśnie próbie hipotetycznego odtworzenia pochodzenia znaczeń tego typu sygnetów drukarskich, gdyż niektóre z nich dziś trudno rozszyfrować.

Podstawę źródłową publikacji stanowiły przede wszystkim dwie książki: Polskie sygnety drukarskie od XV do połowy XVII wieku Katarzyny Krzak-

1 J. Kiliańczyk-Zięba, $W$ cieniu symbolicznego drzewa. O sygnecie drukarskim Macieja Wirzbięty, ,Biuletyn Historii Sztuki” 2010, R. 72, nr 1-2, s. 93.

2 Zob. tamże, s. 94. 
-Weiss oraz zebrane przez Kazimierza Hałacińskiego i Kazimierza Piekarskiego Sygnety polskich drukarzy, ksieggarzy i nakładców: zbiór podobizn $i$ oryginalnych odbić, uzupełnione o inne dostępne publikacje z zakresu tej tematyki. Ponadto autorka przeprowadziła kwerendy m.in. w Bibliotece Jagiellońskiej, Bibliotece Książąt Czartoryskich w Krakowie, Bibliotece Narodowej w Warszawie oraz w Bibliotece Uniwersyteckiej we Wrocławiu i Ossolineum. Materiał źródłowy rozszerzony został o materiały dostępne w bibliotekach i repozytoriach cyfrowych ${ }^{3}$.

Głównym celem, jaki obrała sobie Autorka, było zbadanie drzeworytów pod kątem ich wartości jako środka przekazu informacji, a nie jako dzieła sztuki graficznej. W swoich badaniach Kiliańczyk-Zięba korzystała z metody ikonologicznej, która koncentruje się na symbolice obrazów i ich treści ${ }^{4}$.

Zasięg terytorialny i zakres chronologiczny poruszanej w książce tematyki obejmuje tereny Rzeczypospolitej XVI w. w jej historycznych granicach (Korona oraz Wielkie Księstwo Litewskie), jak również obszary będące wtedy lennem państwa polsko-litewskiego (np. Prusy Królewskie).

Książkę, poza wstępem, zakończeniem i aparatem pomocniczym, podzielono na sześć części. W rozdziale pierwszym Autorka skupiła się na miejscach i częstotliwości występowania sygnetów, a także na ich potencjale identyfikacyjnym i symbolicznym. W części drugiej omówiła tradycje heraldyczne sygnetów, by następnie w rozdziale trzecim zaprezentować sygnety, których wzorce wywodzą się z epoki antycznej. Następna część poświęcona została odwołaniom chrześcijańskim występującym w badanym materiale graficznym. Rozdział piąty ma nieco odmienny charakter, traktuje bowiem nie o całej grupie sygnetów drukarskich, ale o używanych w jednej z krakowskich oficyn - identyfikujących Drukarnię Łazarzową. Ostatnia część charakteryzuje sygnety pojawiające się w publikacjach drukarzy hebrajskich działających na terenie Krakowa i Lublina.

Autorka w rozprawie zachowującej wymagania pracy naukowej zabiera czytelnika w niezwykle pasjonującą podróż po sygnetach XVI w. Mimo wielu niewiadomych podjęte próby odpowiedzi na pytania dotyczące wymowy tych znaków i ich odbioru przez współczesnych wydają się trafne. Książka zasługuje na uwagę nie tylko bibliologów, lecz także filologów, historyków oraz wszystkich zainteresowanych pogłębieniem wiedzy na temat dziejów druku.

Niezaprzeczalnym atutem jest materiał ilustracyjny publikacji, który pozwala zwizualizować omawianą tematykę (na końcu książki znajduje się spis ilustracji ze szczegółowymi danymi rycin wykorzystanych w pracy, któ-

3 Zob. J. Kiliańczyk-Zięba, Sygnety drukarskie w Rzeczypospolitej XVI wieku: źródta ikonograficzne i treści ideowe, Kraków 2015, s. 13.

4 Zob. tamże, s. 23-24. 
rych jest aż 100!). Tom zawiera również bogate zestawienie bibliograficzne, a także niezwykle przydatny indeks osobowo-geograficzny.

Katarzyna Seroka

Warszawa

Catalogue of books from the Library of Sigismund II Augustus, King of Poland, in the collection of the National Library of Russia in Saint Petersburg, ed. by Maria I. Tkachenko, Maria Brynda, National Library of Poland (Warsaw), National Library of Russia (Saint Petersburg), Warsaw: National Library of Poland, 2015, 198 [1] s., [21] s. tabl., ISBN 978-83-7009-621-2.

W sierpniu 2013 r., w ramach obowiązującej od 1993 r. umowy o współpracy, Biblioteki Narodowe Polski i Rosji rozpoczęły pracę nad ilustrowanym katalogiem ksiąg z biblioteki króla Zygmunta Augusta znajdujących się w zbiorach rosyjskiej książnicy narodowej. Projekt w 2015 r. zwieńczony został publikacją Katalogu książek z Biblioteki króla Zygmunta Augusta w zbiorach Rosyjskiej Biblioteki Narodowej w Sankt Petersburgu zawierającego opisy 110 pozycji w 74 woluminach. Wydawnictwo opracowane przez Marię Bryndę (BN) i Marię I. Tkaczenko (RBN) w języku angielskim, opatrzone zostało wstępem także w języku polskim i rosyjskim, przygotowanym wspólnie z Nikołajem W. Nikołajewem (RBN).

Katalog stanowi uzupełnienie dzieła Alodii Kaweckiej-Gryczowej Biblioteka ostatniego Jagiellona. Pomnik kultury renesansowej (Wrocław 1988), która podjęła się rekonstrukcji królewskiego księgozbioru na podstawie ówczesnego stanu wiedzy i dostępnych źródeł. Jednakże na przełomie lat 80 . i 90. XX w. M. I. Tkaczenko, dokonując przeglądu poszczególnych części księgozbioru RBN, odkryła 74 woluminy posiadające charakterystyczne dla biblioteki Zygmunta Augusta oprawy. W trakcie badań okazało się, że 33 woluminy (61 dzieł z uwzględnieniem konwolut) nie zostało ujętych w Bibliotece ostatniego Jagiellona...

Właściwy Katalog książek z biblioteki królewskiej poprzedza wspomniany wyżej wstęp zawierający rys dziejów i historii badań nad księgozbiorem, informacje na temat projektu badawczego realizowanego przez BN i RBN, odniesienie się do monografii A. Kaweckiej-Gryczowej oraz wyjaśnienie zasad opisu przyjętych w Katalogu.

Konstrukcja Katalogu jest zgodna z układem rzeczowym zastosowanym przez A. Kawecką-Gryczową; został podzielony na dwie części. W pierwszej, ze względu na przeważającą ilość, znajdują się książki o tematyce prawnej, 
w drugiej rejestrowane są pozycje należące do pozostałych działów, lecz ze względu na małą liczbę nie zostały pogrupowane zgodnie z ich tematyką, a tylko zestawione $\mathrm{w}$ ciągu alfabetycznym i ponumerowane.

Opis katalogowy jest zgodny z polską normą opisu bibliograficznego starych druków (PN-N-01152-8: 1994). Przy czym w Katalogu wyróżniono dwa rodzaje opisów - edycji wprowadzonych przez A. Kawecką-Gryczową do Biblioteki ostatniego Jagiellona... na podstawie Index Alphabeticus Librorum Iurisprudentiae in Bibliothecam D. Sigismundi II Augusti Polonorum Regis, sporządzonego przez Stanisława Koszutskiego do 1553 r., a $\mathrm{w}$ omawianej publikacji potwierdzonych konkretnymi egzemplarzami, oraz opisy edycji nienotowanych w opracowaniu A. Kaweckiej-Gryczowej.

W opisie katalogowym zawarte zostały także informacje na temat proweniencji i opraw - data oprawy, numer superekslibrisu, numer radełka, małe tłoki (stemple), sposoby zdobienia grzbietu, klauzurowanie, filigrany papieru użytego przez introligatora na wyklejki i karty ochronne oraz informacje na temat stanu zachowania poszczególnych egzemplarzy. Ponadto Katalog wyróżnia się bogatym materiałem ilustracyjnym przedstawiającym m.in. charakterystyczne, zdobione superekslibrisami oprawy z brązowej, cielęcej skóry.

Katalog uzupełniają na końcu m.in.: tabela zawierająca szczegółowe opisy opraw, indeks drukarzy, wydawców, księgarzy i miejsc druku, indeks proweniencji oraz konkordancja sygnatur, konkordancja numerów pozycji w Bibliotece ostatniego Jagiellona... z numerami w Katalogu, konkordancja numerów pozycji z nieznanego A. Kaweckiej-Gryczowej inwentarza biblioteki żółkiewskiej z 1669 r. z numerami w Katalogu, a także indeks nazwisk.

Całość wydawnictwa wykonana została z najwyższą starannością merytoryczną i edytorską.

Karolina Figaszewska Warszawa

Joanna Matyasik, Polonika XVI-XVII w. ze zbiorów Wojewódzkiej i Miejskiej Biblioteki Publicznej w Bydgoszczy. Katalog, Bydgoszcz: Wojewódzka i Miejska Biblioteka Publiczna im. Dr. Witolda Bełzy, 2015, ss. 345, ISBN 978-83-85979-21-0; 978-83-62545-86-5.

Wydany przez Wojewódzką i Miejską Bibliotekę Publiczną w Bydgoszczy katalog poloników XVI-XVII w. autorstwa Joanny Matyasik jest kolejną po katalogu dokumentów i listów królewskich ze zbioru warszawskiego prawnika Kazimierza Kierskiego oraz katalogu inkunabułów ${ }^{1}$ (głównie

Zob. Katalog dokumentów i listów królewskich ze zbioru Kazimierza Kierskiego, opr. J. Eis, Bydgoszcz 2005; Katalog inkunabułów Wojewódzkiej i Miejskiej Biblioteki Publicznej w Bydgoszczy, opr. J. Ociepa, Bydgoszcz 1999. 
należących do zbiorów pobernardyńskich) pozycją przedstawiającą najcenniejsze zbiory tejże Biblioteki. Stare druki ze zbioru „Bibliotheca Bernardina"2 stanowią również dominującą grupę (122 dzieł) w spisie poloników XVI-XVII w., liczącym 490 pozycji bibliograficznych, zawartych w 517 egzemplarzach. Zapisy proweniencyjne pozostałych dzieł wskazują, że należały one do instytucji, towarzystw oraz mieszkańców Bydgoszczy i jej okolic, zwłaszcza ziemiaństwa, ale także i z innych części Polski oraz spoza jej granic. Historia tej kolekcji stanowi odzwierciedlenie powojennych losów okolicznego ziemiaństwa - Skórzewskich (właścicieli dóbr łabiszyńskich z siedzibą w Lubostroniu oraz ordynacji radomicko-czerniejewskiej) z liczącą ok. 70000 woluminów biblioteką ${ }^{3}$, Kruszyńskich i Sczanieckich z księgozbiorem zgromadzonym w Nawrze ${ }^{4}$, Kalksteinów z Pluskowęsów ${ }^{5}$, Ponińskich z Kościelca Kujawskiego ${ }^{6}$.

Zasób starych druków WiMBP w Bydgoszczy liczy 8245 woluminów, wśród których znajduje się ok. 2000 poloników, z czego 95 - z XVI w., dwa - z przełomu XVI i XVII w. oraz 393 - z XVII w. Biblioteka zdecydowała się na przyjęcie w katalogu nietypowego zakresu chronologicznego ze względu na specyfikę swoich zbiorów. Planuje w przyszłości wydanie katalogu poloników XVIII w. (ok. 1500), który dopełni obraz tej grupy jej zbiorów? .

Ujęty w publikacji wykaz poloników XVI-XVII w. tworzy spójny typograficznie zbiór. Najstarsze prezentowane w nim dzieło to Opusculum eruditum... Filipa Beroaldo wydane w Erfurcie ok. 1505 r. Do najcenniejszych zaliczyć można m.in. zachowane tylko w kilku egzemplarzach pierwsze wydanie Chronica Polonorum Macieja z Miechowa z 1521 r. z licznymi ilustracjami drzeworytowymi oraz druki z najstarszych polskich oficyn, przede wszystkim krakowskich (np. Parvulus philosophiae naturalis... z objaśnieniami Jana ze Stobnicy, wydany w 1513 r. przez Jana Hallera i Floriana Unglera), ale także

2 Księgozbiór pobernardyński liczy 1381 woluminów, głównie z XVI i XVII w. Do najcenniejszych zaliczyć należy 97 inkunabułów, wśród których znajdują się cymelia i unikaty.

3 Zob. R. Nowicki, Skórzewscy. Właściciele dóbr tabiszyńskich. Rola w życiu społecznopolitycznym wielkopolskiego ziemiaństwa, Torun 2003; tenże, Semper Recte. Z dziejów rodu Skórzewskich, Lubostron 1998.

4 Zob. B. Chrapkowski, S. Wierzchosławski, Nawra - gmina Chetmża. Zespół pałacowoparkowy, Torun 1995, s. 7-17, 30-31; J. Dygdała, S. Wierzchosławski, Nawra Kruszyńskich i Sczanieckich. Studium z dziejów szlachty i ziemiaństwa ziemi chełmińskiej, Torun 1990, s. 71-73, 150-165; F. Stolkowski, Nawra z tamtych lat, Toruń 2014, s. 174-180.

5 Zob. J. Chrostowska, B. Zobolewicz, Pluskowęsy gmina Chetmża. Zespót pałacowoparkowy, Toruń 2000, s. 14-33.

6 Zob. R. Nowicki, Fragment księgozbioru Ponińskich z Kościelca w zbiorach Wojewódzkiej i Miejskiej Biblioteki Publicznej w Bydgoszczy, „Biblioteka” 2007, nr 11, s. 29-44.

7 WiMBP w Bydgoszczy posiada trzy wartościowe kolekcje, wyodrębnione ze względu na ciągłość historyczną: „Bibliotheca Bernardina”, listy królów i osobistości polskich oraz teatralia, będące darem od dramaturga i krytyka teatralnego Adama Grzymały-Siedleckiego. 
dzieła zawierające ryciny najwybitniejszych przedstawicieli grafiki polskiej w owych stuleciach, np. gdańskiego rytownika Jeremiasza Falcka, współpracującego z oficyną Georga Förstera, śląskiego miedziorytnika Dawida Tscherninga, pracującego dla Łukasza Kupisza czy Franciszka Cezarego.

Oprócz dzieł licznie reprezentujących oficyny krakowskie oraz inne małopolskie (Lublin, Zamość, Sandomierz, Jarosław) w zbiorze poloników znajdują się również druki wydane w Wielkopolsce (Kaliszu i Poznaniu), na Mazowszu (w Warszawie) oraz Pomorzu (w Gdańsku, Szczecinie, Oliwie, Toruniu, Elblągu, Sopocie, Braniewie), tudzież publikacje z Wilna, Lwowa, Dobromila, Królewca, czy Słucka. Oficyny działające poza granicami ówczesnej Rzeczypospolitej w katalogu są reprezentowane przez druki tłoczone w Szczecinie i Kołobrzegu. Wśród oficyn zagranicznych przeważają niemieckie (m.in. z Kolonii, Frankfurtu nad Menem, Wittenbergi) oraz z terenów dzisiejszej Holandii i Belgii. Listę zagranicznych oficyn domykają dzieła wydane we Francji, Włoszech, Austrii i Szwajcarii.

Pod względem treściowym prezentowana kolekcja jest różnorodna, z przewagą druków o tematyce religijnej (teologia pastoralna, homiletyka, żywoty świętych, mszały, literatura dogmatyczna i apologetyczna, rozważania polemiczne, dzieła panegiryczne, różne wydania Biblii, komentarze biblijne), w tym wszystkie trzy wydania Biblii Leopolity z 1561, 1575 i 1577 r. krakowskiej oficyny Szarfenbergów oraz dzieła polemiczne Jakuba Wujka, Adriana Jerzego Junga i Fabiana Adama Birkowskiego, hagiograficzne (np. Piotra Skargi czy Adama Opatowczyka) oraz bogaty zbiór kazań. Licznie reprezentowane są także polonika z zakresu filozofii scholastycznej i humanistycznej oraz prawa, historii, polityki i dyplomacji, ekonomii, filologii (retoryka, gramatyka i słowniki), nauk ścisłych (geografia, matematyka, astronomia, przyroda, medycyna), jak również literatura piękna.

Katalog składa się z czterech części: pierwszą stanowi wstęp wraz z wykazem skrótów i literaturą, drugą - alfabetyczny spis druków, trzecią - aneksy. Czwarta to 16 ilustracji przedstawiających najciekawsze i najbardziej wartościowe polonika w postaci rycin miedziorytniczych lub drzeworytniczych (np. frontyspisy, tablice, finaliki, kolofony, ozdobne ramki), stanowiących przykłady polskiej sztuki typograficznej w XVI i XVII w., a także fotografie ciekawych opraw, pieczęci władców, pieczęci i zapisów proweniencyjnych, jak i gloss oraz marginaliów. Spis przygotowano w oparciu o normę opisu bibliograficznego starych druków (Opis bibliograficzny-Stare druki PN-N-01152-8: 1994). Autorka przyjęła przy tym własne rozwiązania m.in. odnośnie do szeregowania w porządku alfabetycznym, nie wyodrębniając polskich znaków (po-

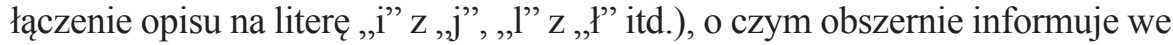
wstępie (s. 8-11). Katalog został zaopatrzony w szereg aneksów niezbędnych do poruszania się po nim. W kolejności są to: konkordancja sygnatur i nume- 
rów katalogu; indeks autorów, tłumaczy, komentatorów, redaktorów, autorów dzieł w pracach zbiorowych, osób występujących w tytułach; indeks drukarzy, nakładców, księgarzy, firm wydawniczych i księgarskich; wykaz druków według miast, drukarzy, nakładców, firm wydawniczych i drukarskich, a także indeksy: chronologiczny, autorów dedykacji, adresatów dedykacji, autorów aprobaty, autorów rycin, proweniencji oraz wykaz ilustracji zawartych w katalogu.

Katalog poloników XVI-XVII w. opracowany przez J. Matyasik jest wartościowy nie tylko ze względu na prezentację zasobów i dziejów kształtowania się kolekcji starych druków WiMBP w Bydgoszczy. Stanowi także ważną pozycję w warsztacie badawczym księgoznawców, bowiem spełnia wymogi stawiane naukowym wydawnictwom katalogowym i bibliograficznym.

Agnieszka Chamera-Nowak

Warszawa

Polski wklad w przyrodoznawstwo i technikę: stownik polskich i zwiqzanych z Polska odkrywców, wynalazców oraz pionierów nauk matematyczno-przyrodniczych i techniki, t. 1-4, red. nauk. Bolesław Orłowski, Warszawa: Instytut Historii Nauki im. Ludwika i Aleksandra Birkenmajerów Polskiej Akademii Nauk, Instytut Pamięci Narodowej - Komisja Ścigania Zbrodni przeciwko Narodowi Polskiemu, 2015, t.1 ss. 521, t. 2 ss. 437 , t. 3 ss. 511 , t. 4 ss. 543, ISBN 978-83-8606-229-4; 978-83-8606$228-7$; 978-83-7629-829-0; 978-83-7629-828-3; 978-83-7545-569-4; 978-83-7545-570-0.

Stownik polskich i związanych z Polska odkrywców, wynalazców oraz pionierów nauk matematyczno-przyrodniczych i techniki jest wynikiem współpracy Instytutu Historii Nauki PAN, jako inicjatora projektu, oraz Instytutu Pamięci Narodowej, który sfinansował wydanie tego czterotomowego dzieła. Celem powstania słownika była chęć ukazania czytelnikowi wkładu i dokonań polskich uczonych na polu techniki i nauk matematyczno-przyrodniczych, omijanych do tej pory w samodzielnych opracowaniach encyklopedycznych i słownikowych. We wstępie czytamy o tendencji polskiego społeczeństwa do zniekształcania wyobrażenia o polskiej kulturze przez przesadne docenianie rangi polskiej literatury, przy jednoczesnym pomijaniu licznych i znaczących dokonań polskich uczonych na polu nauk przyrodniczych. Lekceważenie, bądź niewiedza o wkładzie Polaków w światową technikę znacznie wpływa na samoświadomość historyczną polskiego spo- 
łeczeństwa. Autorzy słownika mają nadzieję na jej modyfikację za sprawą rzetelnie opracowanego dzieła. Biogramy zostały opracowane przez ponad 100 autorów, sporządzono ok. 1200 haseł dotyczących naukowców żyjących od XIII w. do współczesności. Dzieło powstawało przez sześć lat. Kryterium wyboru osobowości mających znaleźć się w słowniku była oryginalność i innowacyjność osiągnięć, same zaś biogramy skupiają się na najważniejszych dokonaniach, wspominając pozostałe znaczące i charakterystyczne elementy biografii przedstawionych postaci. Sam wyznacznik polskości został potraktowany nierygorystycznie. W słowniku znaleźli się również cudzoziemcy działający na terenie Polski, jak i Polacy działający na obczyźnie. Na początku pierwszego tomu znajduje się nota od redaktora naukowego słownika, następnie wstęp oraz krótki zarys zmiennych historycznie warunków uprawiania przez Polaków nauk przyrodniczych, ścisłych i techniki (w Polsce i poza jej granicami), również autorstwa B. Orłowskiego. Każdy z czterech tomów zawiera listę najczęściej używanych skrótów, skróty pozycji bibliograficznych oraz listę autorów. Każdy biogram kończy się bibliografią. Prawie każde hasło posiada czarno-białą miniaturę fotografii. Wszystkie tomy słownika uzupełnione są źródłami ilustracji. Słownik zadedykowany jest pamięci profesora Jerzego Dobrzyckiego, dyrektora Instytutu Historii Nauki PAN w latach 1990-1995, astronoma i historyka nauki, który bardzo przyczynił się do rozwoju badań nad historią nauk ścisłych i przyrodniczych prowadzonych w Instytucie.

Sarah Skumanov

Warszawa 